\title{
EARLY EDUCATION MATTER: THE POWER OF CHILD-PARENT ATTACHMENT QUALITY IN PREDICTING CHILD'S EXECUTIVE FUNCTION
}

\author{
Yuliana Mukti, Donny Hendrawan*)
}

Faculty of Psychology, Universitas Indonesia, Depok 16424, Indonesia

*) Email: donny.hendrawan@ui.ac.id

\begin{abstract}
Parental caregiving is a cornerstone of child's early education primarily their cognitive performance. A positive attachment quality has proven to contribute to the child's higher-order thinking process, supported by cool and hot executive function (EF) skills. However, previous studies still found inconsistencies, particularly of which cool and hot EF components are being affected. Moreover, the presence of mother and father figure in parenting enriched the finding of child EF, but studies about father's figure related to child attachment quality are still limited. This study was a preliminary study that aimed to investigate the relationship between child's attachment quality with both mother and father and child's cool and hot EF on preschoolers. Child's attachment quality was assessed using ASCT (Attachment Story Completion Task) and child's EF was measured using Executive Function Battery Test. All of the activities were videotaped. Partial correlation was used to investigate the relationship between child attachment quality and child EF while gender, age and child attachment with one of the attachment figure are controlled. The result found that controlling variables influence the correlation between child's attachment quality and EF skills. This study presented important finding to improve the quality of early education through ameliorating parent-child relationship.
\end{abstract}

Keywords: executive function, preschooler, quality of attachment

\section{URGENSI PENDIDIKAN USIA DINI: KEKUATAN KUALITAS ATTACHMENT DALAM MEMPREDIKSI EXECUTIVE FUNCTION ANAK USIA PRASEKOLAH}

\begin{abstract}
Abstrak
Pengasuhan merupakan hal penting dalam pendidikan usia dini terutama berkaitan dengan performa kognitif yang dimiliki anak. Kualitas attachment yang adaptif terbukti memprediksi pemrosesan informasi yang dilatarbelakangi oleh kemampuan cool dan hot executive function (EF). Namun, temuan penelitian sebelumnya masih tidak konsisten, utamanya terkait komponen EF yang terprediksi berkaitan dengan kualitas attachment. Di sisi lain, keterlibatan ibu dan ayah dalam pengasuhan memperkaya temuan terkait EF anak, tetapi penelitian mengenai peran ayah berkaitan dengan kualitas attachment masih terbatas. Penelitian ini merupakan study awal yang bertujuan untuk mengetahui hubungan antara kualitas attachment yang dimiliki anak baik dengan ibu maupun ayah dan kemampuan cool dan hot EF pada anak usia prasekolah. Kualitas attachment diukur menggunakan ASCT (Attachment Story Completion Task) dan kemampuan EF menggunakan battery-test EF. Semua kegiatan pengukuran direkam. Korelasi parsial digunakan untuk mengetahui hubungan antara kualitas attachment anak dan kemampuan EF anak dengan mengontrol jenis kelamin dan usia anak serta kualitas attachment yang anak miliki dengan figur orang tua yang lain. Hasil penelitian menemukan bahwa variabelvariabel yang dikontrol ikut serta memprediksi adanya hubungan antara kualitas attachment dan kemampuan EF anak. Penelitian ini menggambarkan temuan penting untuk meningkatkan kualitas pendidikan anak usia dini dengan memupuk hubungan antara orang tua dan anak.
\end{abstract}

Kata kunci: kualitas attachment, executive function, anak usia prasekolah

\section{INTRODUCTION}

Early education is the primary foundation for the child later development. The first education for the children are given by their parent in parenting practice, and it became a core unit of the learning process (Hughes \& Ensor, 2009). The parent helped their child through their behavior about information and knowledge in which their children did not know before (Lewis \& Carpendale, 2009; Carlson, Zelazo, \& Faja, 2013). This interaction was happened in a daily parent-child relationship in caregiving context and contributed to the development of selfregulation process which was the primary goal of early education (Blair, 2016). Parent-child 
relationship of early childhood arguably constitutes the most intense and enduring relationship, thereby representing the very core of the young child's environment and thus affect their cognitive, social and emotional development (Schore, 2001; Belsky \& De Haan, 2011; Setyowati, Krisnatuti \& Hastuti, 2017). One of the manifestations of this relationship is reflected in child's quality of attachment to their parents (Marvin, Britner, \& Russel, 2016). Attachment relationship facilitates children to explore the environment with the feeling of comfort and safety from the presence and availability of the attachment figure, and the quality itself is related to the parent's behavior towards the child's needs. Many findings have shown the contribution of child's quality of attachment in various developmental aspects including child's executive function (EF).

Child's attachment quality is said to have an impact on the development of child's EF a neurocognitive process arguably enables the child to regulate their behavior. It consists of two domain called cool EF and hot EF differentiated by the context of the situation (Hughes \& Ensor, 2009; Lewis \& Carpendale, 2009; Zelazo \& Carlson, 2012; Diamond, 2013; Carlson, Zelazo, \& Faja, 2013; Carlson, 2009). Cool EF is considered as a set of higher neurocognitive function that facilitates children to process abstract information, while hot EF is more involved in processing complex information triggered by emotion and motivation that highly related to one's emotion regulation. The development of EF skills was a substantial factor in early education because these skills were correlated with a subsequent cognitive function which became the target of recent curriculum system (Blair, 2016; Diamond, 2013; Cartwright, 2012). These skills have proven their contributions to child school readiness (Welsh et al., 2010) and math and reading skill (Blair \& Razza, 2007; Cole, Duncan \& Blaye, 2014). The main component of EF develops since infancy and more elaborated in preschool age and shapes a basic foundation of EF which builds higherorder thinking process that will remain until adulthood (Garon, Bryson \& Smith, 2008; Anderson \& Reidy, 2012). It indicated the crucial affair between early attachment relationship and EF development. Previous studies have shown that child's quality of attachment contributed significantly to child's cool EF (Bernier et al., 2012). This result was also significant in a study which assessed cool EF both performance task and teacher report measurement (Bernier et al., 2015), as well as in research which only evaluated hot EF (Jacobsen et al.,1997).

However, there are still some inconsistencies related to the component of child's EF. The discrepancies were presumably caused by the differences context such as methodological consideration in which the research is conducted, whether in a laboratory or home setting. Home setting is considered to represent more natural and familiar environment for the children compared to the laboratory setting to gather observational data (Farnfield \& Holmes, 2014; Moss et al., 2014; Posada et al., 2007). These differences have directed to the different performance of the child. The study as in Bernier et al. (2012) and Bernier, et al. (2015) that used the home-visit procedure of AQS (Attachment Questionnaire Sort) found that child's secure and insecure attachment quality associated with child's cool $\mathrm{EF}$. On the other hand, a study conducted by Rosche (2013) that used the laboratory-setting with SSP (Strange Situation Procedure) found that child's secure and insecure attachment quality contributed significantly only to child's hot EF. Specifically, Bohlin et al. (2012) which also used a laboratory-setting, namely ASCT (Attachment Story Completion Task) that arguably less stressful procedure than SSP, found that child's insecure attachment has a non-significant contribution to one of the components of cool EF namely inhibitory control. The same method conducted by Thorell, Rydell, and Bohlin (2012) also found that child's insecure attachment quality has not correlated with child cool EF, i.e., inhibitory control and working memory. These different results may be related to the manifestation of emotional context and the pressuring circumstance experienced by the children from the methodological approach of the attachment quality measurement. This condition is known to be related to overlapping neurocognitive process of child's cool and hot EF under stressful and neutral situation (Zelazo \& Müller, 2011).

Moreover, the presence of father figure has been a growing interest in most research related to caregiving environment. Research explained that father's appropriate response, both emotionally and behaviorally, in caregiving context holds a crucial role in contributing to the improvement of child's EF (Towe-Goodman et al., 2014). Other research related to father's support and control have also proven to contribute to child's EF (Meuwissen \& Carlson, 2015; Hertyas et al., 2016). Although many studies have examined 
about father's role, to our knowledge little is known about the role of father's attachment on the development of EF in children. Meanwhile, some studies found differences between child's attachment quality with mother and father, which also affected different aspects of child's later development (Bretherton, 2010; Bureau et al., 2014). These findings suggested potential factor for father's role to influence the development of child's EF through the quality of attachment to his child.

This current study aims to investigate the relationship between child's quality of attachment, both with mother and father, and child's EF, both cool and hot EF, to add up to the gap from the previous findings on related issues. Hopefully, the results of this current studies can be implemented in the early educational system which emphasizes the participation of the parents, both mother, and father, in supporting the potential development of the children since they are in early ages through their high-quality of their relationship with their children. This study also takes into consideration some factors such as child's age and gender because previous research found that child's age and gender could predict cool EF, hot EF and both domain (Hendrawan et al., 2015). This study hypothesizes that child's quality of attachment, both with mother and father, will have associated with both child's cool and hot EF, along with other aspects influenced by child's quality of attachment.

\section{METHOD}

This research is non-experimental research design and using observational measurement to collect the data about the child's attachment quality and EF skills. The child's quality of attachment in this research described in child's mental representation of the attachment relationship between the child and their mother and father. The EF skills defined in the child's performance when they complete the EF battery-task. This research is preliminary research involving 42 preschool children as participants with a range of age 48-72 months.

This research conducted in the kindergartens and daycare based in Kota Depok, West Java Province. The study held in April until June 2017 in three different among others were two in private school which have moderate to highincome family and one in public school which has moderate to low-income family. The observational measurement of the child performance both their quality of attachment and EF skills have done in the quiet room in the school which prepared by the researcher and school principal to avoid any disturbance that may occur during the test.

The participation of the child in this research using purposive sampling in which the children got through the screening procedure before participating in this research. The screening procedure was conducted to determine that the age of the child meets the criteria of this research, the child did not have any history of severe developmental problems, the child used Bahasa Indonesia as daily language and lived with his/her father and mother.

The process initiated with visited some kindergartens and daycares to gather permissions from each of the School Principals to conduct research involving their students' participation. Researcher informed the parent about the research afterward. Parents were invited to collect their informed consent and required to fill the Children and Parents Personal Data Forms with the assistance of the teacher. This form aimed to collect information about children's age, socioeconomic status of the family and other information about the child's health as well as their child's cognitive development history as means for screening. The child with no indication of any problems regarding their developmental milestone and are within the age criteria were asked to perform the tests in two sessions. In the first meeting, the tester measured three subtests of cool EF (Rumput/Matahari task, Backward Word Span [BWS] task, Dimensional Card Sorting [DCCS] task) and hot EF task (Gift Delay task). Child's attachment quality using ASCT was also measured with one of the parental figures (father or mother) in one day, and the other one on the second day which took place within range of 2-3 days after to avoid the spill-over effect. The order of the attachment figure was counterbalanced. The duration of the first and second meeting lasted for $\pm 30-45$ minutes and $\pm 15-20$ minutes respectively and was videotaped for further coding and scoring.

EF skill was assessed with EF battery-test with contained several tasks that have been adapted to Bahasa Indonesia by the researcher as in (Hendrawan et al., 2015). The test administration was conducted by a qualified tester. The order of the test administration begins with The Rumput/Mahari task, The Backward Word Span (BWS) task, The Dimensional Card Sorting Task (DCCS) and Delay of Gratification task. 
The Rumput/Matahari task. The Rumput/Matahari task adapted from the Grass/Snow task by a study as in (Carlson, White \& Davis-Unger, 2014) to measure child's inhibitory control skill. In this task, the child was asked to point out a green card when the tester mentioned the word "Matahari" and pointed out the yellow card when the tester mentioned the word "Rumput". The subtest contained 16 trials with a random sequence. The correct answer is given 1 point, and the wrong answer is given 0 point. The maximum total score is 16 .

The Backward Word Span (BWS) task. This test is the second test administered to the child, which aims to measure child's working memory skill. The task was adapted from researchers as in (Carlson, White \& DavisUnger, 2014) and required the child to repeat the words spelled by the tester in backward order. There were five levels, in which each level describes the number of words that have to be repeated in backward order. The child was given three chances that he/she needed to repeat by the reverse sequence in each level. In the first level, the child is given 1 point if he/she succeeded in repeating the words spelled by the tester in backward order during the trial session. In the second level, the child is given 2 points if he/she succeeded to repeat two words in backward order. This rule was applied on the third, fourth and fifth level as well, and the maximum score for this task is 5 points.

The Dimensional Card Sorting (DCCS) task. The third subtest is the DCCS which was adapted from a study as in (Zelazo, 2006) to measure child's set shifting skill. The test involved colored cards (red and blue) on the two pictures (flower and house) where the child was asked to put the card into a box according to the rules are given. There are three levels with different rules in this task. In the first level, the child is asked to put the card into a box based on the same color. The second level the card must be placed based on the same picture. In the third level, namely the border stage, the child is asked to put the card with the black border around the picture based on the color and put the card without black border based on the picture. One point is given if a child was able to put the cards into the box with maximum one mistake within the first and second level and maximum three mistakes in the third level (border stage). The total point if a child succeeds in all of the levels on this task is 3 point.
The Gift Delay task. The last measurement section of the EF skill is the task where the child is asked to wait and keep looking straight ahead while the tester is wrapping the gift for 2 minutes. This task was conducted to measure hot EF which adapted from the research as in (Carlson, White \& Davis-Unger, 2014 where the researcher assessed the duration of the first time the child peeps, the frequency of the peeping, and the way the child is peeping when the tester is wrapping the gift. The total point of this task was obtained from a standardized score of a gathered point of that three aspects.

The attachment quality. In this test, the child was asked to complete a story adapted from ASCT (Attachment Story Completion Task) by a study as in (Verschueren \& Marcoen, 1999). The test contains five stories related to the context of attachment of the child with his/her parents. The stories are Sepeda yang dicuri (The Stolen Bicycle), Hadiah (The Present), Minta Maaf (I'm Sorry), Berkelahi di Sekolah (Quarreling at School), and Monster di Kamar Tidur (Monster in the Bedroom). The administration of this test was aided by figuring dolls representing figures of mother, father, son, and daughter. At the beginning of the trial, the child asked to choose one figure of the son or daughter doll that represents him/her the most. The tester then started to tell the story and stopped in the middle of the climax and then asked the child to complete and finish the story. All of the five stories have the score ranging from 1 to 5 . Every score represented different occasions that the children encounter. Score 1 was given to the child who has a lowsecurity level which is reflected in the child's story that his/her father/mother is/are not responsive and insensitive to his/her needs. The highest score, 5 , is given when a child is having a high level of security, which is reflected by the child's feeling that his/her father/mother was available and having the appropriate response to his/her needs signals particularly regarding the experience of conflict. The test administration was videotaped. Raters rated the video and obtained the reliability with inter-rater correlation value with 0,85 for the video measuring child's attachment quality with mother figure and 0,77 for the video measuring child's attachment quality and father figure.

Observational measurement of the child's quality attachment using ASCT provided the score of the child attachment quality from each story. Each of the score from five stories summed up afterward and generated a global 
score which represented the child's attachment quality. This coding process enacted both in child's attachment quality with mother figure and father figure. On the other hand, the scores of EF skills were standardized and assembled as a composite score. Correlation analysis was conducted using the score of child's attachment quality with both mother and father and child cool and hot EF. Afterwards, partial correlation analysis was conducted to comprehend the correlation of child's attachment quality with child's EF skill, by controlling child's attachment quality, gender, and age.

\section{RESULT}

Participants of this research were 42 preschool children with 25 boys and 17 girls. The mean of their age was 62,86 months $(S D=4,93)$, the mean of cool and hot EF were 0,000002 $(S D=2,1) \quad$ and $0,000001 \quad(S D=2,3)$ subsequently. The mean for child's attachment quality with mother was $15,17(S D=5,53)$, and father was $16,25(S D=5,2)$. The result found a significant correlation between child's attachment quality with mother and child's cool EF $(r=0,479, p<0,05)$ and hot EF $(r=0,315$, $p<0,05)$. The same significant correlation also found in child's attachment quality with father and child's cool EF $(r=0,406, p<0,05)$ and hot EF $(r=0,280, p<0,05)$. The correlation between age and child's EF, both cool and hot EF did not find any significant result. Meanwhile, the gender correlated significantly with hot EF and found a non-significant correlation with cool EF. The following analysis explained the result of partial correlation analysis which described the correlation between child's attachment quality with mother and child's cool and hot EF skill, if the child's attachment quality with father, gender, and age are controlled.

Table 1 Partial correlation of child's attachment quality with mother and child's EF by controlling child's attachment quality with father, gender, and age.

\begin{tabular}{|c|c|c|c|c|}
\hline $\begin{array}{l}\text { Control } \\
\text { Variable }\end{array}$ & & $\begin{array}{c}\text { Attachmen } \\
\text { Quality of } \\
\text { Child and } \\
\text { Mother }\end{array}$ & $\begin{array}{c}\text { Cool } \\
\text { EF }\end{array}$ & $\begin{array}{l}\text { Hot } \\
\text { EF }\end{array}$ \\
\hline \multirow{2}{*}{$\begin{array}{l}\text { Attachment } \\
\text { Quality of } \\
\text { Child and } \\
\text { Father, } \\
\text { Gender } \\
\text { and Age }\end{array}$} & $\begin{array}{l}\text { Attachment } \\
\text { Quality of } \\
\text { Child and } \\
\text { Mother }\end{array}$ & 1 & & \\
\hline & $\begin{array}{l}\text { Cool EF } \\
\text { Hot EF }\end{array}$ & $\begin{array}{l}, 300^{*} \\
, 050\end{array}$ & $\begin{array}{l}1 \\
, 158\end{array}$ & 1 \\
\hline
\end{tabular}

Table 2 Partial correlation of child's attachment quality with father and child's EF skills by controlling child's attachment quality with mother, gender, and age.

\begin{tabular}{|c|c|c|c|c|}
\hline $\begin{array}{l}\text { Control } \\
\text { Variable }\end{array}$ & & $\begin{array}{c}\text { Attachment } \\
\text { Quality of } \\
\text { Child and } \\
\text { Father }\end{array}$ & $\begin{array}{c}\text { Cool } \\
\text { EF }\end{array}$ & $\begin{array}{l}\text { Hot } \\
\text { EF }\end{array}$ \\
\hline \multirow{2}{*}{$\begin{array}{l}\text { Attachment } \\
\text { Quality of } \\
\text { Child and } \\
\text { Mother, } \\
\text { Gender } \\
\text { and Age. }\end{array}$} & $\begin{array}{l}\text { Attachment } \\
\text { Quality of } \\
\text { Child and } \\
\text { Father }\end{array}$ & 1 & & \\
\hline & $\begin{array}{l}\text { Cool EF } \\
\text { Hot EF }\end{array}$ & $\begin{array}{l}, 063 \\
, 111\end{array}$ & $\begin{array}{l}1 \\
, 156\end{array}$ & 1 \\
\hline
\end{tabular}

The result in Table 1 described a significant correlation between child's attachment quality with mother and cool EF skills. Within this analysis, there was a non-significant correlation between child's attachment quality with mother figure and hot EF skill, when the child's attachment quality with father, gender, and age were controlled. This analysis also describes that child's cool EF was not correlated significantly with child's hot EF.

The next result of partial correlation analysis illustrates the correlation between child's attachment quality with father and child's cool and hot EF skill if the child's attachment quality with mother, gender, and age are controlled. The result described in Table 2 found that there was a non-significant correlation between child's attachment quality with father and child's cool EF skills as well as hot EF skill when child's attachment quality with mother, gender, and age are controlled. From this analysis, the child's cool EF did not correlate significantly with child's hot EF.

\section{DISCUSSION}

This research explains the contribution of attachment quality between the child and the parents to cool and hot EF of the preschool children. The result illustrated the correlation between child's attachment quality with mother and child's cool EF which has shown a significant relationship when child's quality attachment with father, age, and gender are controlled. This result described that the higher the secure attachment quality that a child has, the higher their cool EF skills. This finding corresponds with previous findings from Bernier et al., (2012) and Bernier et al., (2015) that also found the contribution of secure attachment quality between the child and their mother on child's cool EF either through a 
performance-based task or teacher report. The direction of this finding indicated that the more children feel secure, the higher their cool EF skills. It can be concluded that the children who have a good quality of attachment relationship tend to have more capacity to regulate their behavior. It means they could to manage their appropriate response, to manipulate the information given by the environment in their mind, and to control their attention compared to the children with the lower security level.

The secure quality attachment will make a child feel confident and safe in exploring the surrounding environment (Bretherton, 2010; Cassidy \& Shaver, 2016). Therefore, a child with secure attachment quality has the more prominent opportunity to explore the environment further than a child with insecure attachment quality. It was also supported based on the fact that the secure attachment quality of a child was formed by the parents' response and sensitiveness in responding to the child's signal of needs correctly (Marvin, Britner, \& Russell, 2016; Cassidy \& Shaver, 2016). So the child felt that their parent will be available and responsive, notably when they encountered a conflict. The child who explores the environment has more learning experience which in turn indirectly increased their capacity for cool EF skill. The secure attachment quality that children have also helped the children to engage in the interaction with others efficiently, so they encountered a more positive relationship with others. Consequently, children tend to get easily blend in the interaction with other people outside the family, e.g., with their teacher in the school environment (Williford, Carter, \& Pianta, 2016). Moreover, the interaction that happened in a secure attachment relationship between the children with their mother built internalization of self-regulation from an external source by the help of the mother. Interaction of secure attachment relationship could happen numerously in daily life between mother and their child included in the problem-solving context (Raikes \& Thompson, 2008). This condition facilitated the children to practice their cool EF skills which promote their higherorder thinking process and in turn become more adaptive cognitively and socially.

However, current research has proven an insignificant correlation between child's attachment quality with mother and child's hot EF skills. This finding was not consistent with several other studies that found the contribution of attachment quality to child's EF skill (Jacobsen et al., 1997; Rosche, 2013). It might be related to many other factors that affect the EF skills aside from the attachment quality. The non-significant result might also be caused by the applied method which did not represent a significant emotional context for the child so that the information processing was dominated by cool EF skills. According to researchers as in (Zelazo \& Müller, 2011), this result might occur in a high-pressure context, where the work of cool EF was dominated by hot EF, while a low-pressure context will result in the opposite stance. In this current research, children have not situated in a pressuring circumstance like separation and reunion in Strange Situation Procedure applied in the study as in Rosche (2013). Therefore, this current research did not yield any significant result between the child's attachment quality with their mother and child's hot EF skill.

Contrary to this study hypothesis, the result shows no significant relationship between child attachment quality with father and their cool and hot EF skills when child's attachment quality with mother, gender, and age was controlled. In fact, the role of child's attachment quality with father has shown it contribution regarding other aspects of child development. In other research, attachment quality between the child and his/her father has proven to contribute to child's social and emotional developmental aspects (Bureau et al., (2014). Furthermore, Bretherton (2010) stated that quality of attachment between a child and his/her father became more elaborate after infancy period and occurred in the playing context. This consideration has directed to the conclusion that there is a significant role of child's attachment quality with father on the child's EF skills development. However, the role of child's attachment quality with father in the development of child's EF has not elaborated yet. Presumably, this non-significant finding in this current study was influenced by several factors. They are the duration and frequency of time that father spent for their child concerning their limited work schedule or the dominance of mother role in the home environment including in the parenting context (Hertyas, et al., 2016; Bretherton, 2010). Considering that the relationship between child's attachment quality with father and child's EF skill, both cool and hot EF, was significant when the child's attachment quality, gender, and age was not controlled represented the significant role of a mother figure in caregiving context that could influence the role of father. Moreover, child's age and gender-related with 
the organization of child's quality attachment with father figure might become consideration that differentiates the formation of child quality attachment between mother and father related with the differences of their interaction with their child in caregiving context. Further research is needed to more elaborate the father's role in the organization of child's attachment quality so its contribution to another aspect could be identified thoroughly.

Adding the gap of the previous findings, the evidence from this novel research should be taken into consideration to improve child's selfregulation as a primary focus on early childhood education (Blair, 2016) primarily through optimizing their EF skills with cultivating parent-child attachment relationship since early ages of the children. Parents were supported to be more sensitive and responsive in a more appropriate way to response their children need signals so they could explore the environment more and in turn enhance their EF skills. Moreover, many studies about parent's sensitivity, have known to be associated with the development of child's EF skill (Bernier et al., 2012; Towe-Goodman et al., 2014; Meuwissen,\& Carlson, 2015; Whipple, Bernier,\& Mageau,2011). These have an impact on academic performance (Williford, Carter, \& Pianta, 2016). These represented the important role of attachment quality which could be cultivated by the parent since the very beginning of the child's life.

From this research, we could also take into consideration about the primary goals of early education in the preschool period in which the developmental circumstance nowadays prompt the parent to send their child to enter the school in the earlier age but omitting the role of their own rules. This research was a preliminary study of more complex child-parent attachment relationship which aims to investigate the role of parent both mother and father in their early cognitive development. The findings of this preliminary research support the ideas that early education should be started not only in the class and hand over the duties to educate the child to the teacher, but the early education system should start from home where mother and father work together so the children could reach their optimal development. This idea was proven through this research and supported by the previous studies which found that the child with secure attachment with their parent developed better reading and pre-reading skills, pre-literacy skills and pre-mathematics skills (Williford, Carter, \& Pianta, 2016). Previous research found that the school environment such as the type of the teachers, the facilities, and the activities on the classroom could enhance the child's EF skills (Blair, 2016; Cartwright, 2012) but the primary foundation of the child development started in the interaction of the parents and their children. One of that interaction reflected in their quality of attachment. The child with secure attachment relationship was reported to have better working memory skill (Villano et al., 2014) and longer attentional span (Waters \& Thompson, 2016) than a child with insecure attachment. The children who have insecure attachment relationship with their parent tended to display lower academic achievement compared with the children who have secure attachment relationship with their parent. Villano et al., (2014) also found that children with secure attachment relationship have better ability to receive, maintain and manipulate the information than insecure children. From this research, we could conclude that the child with secure quality attachment tends to more ready to entry schooling system than the child with insecure attachment.

The current study has successfully described the role of child's attachment quality both with mother and father independently and their interaction in predicting child's EF skills based on their performance based task when the children are in the preschool age. The subsequent study might considerate other factors that could influence child's EF skills, such as SES, child's birth order, child's IQ and verbal ability. These factors were not controlled in this study and become a limitation of the researcher when conducted this study. Previous research also needs to elaborate the child's insecure attachment quality which was divided into two categories, avoidant and ambivalent attachment that have a different pattern of behavior when they encounter stressful event.

\section{CONCLUSION AND SUGGESTION}

The quality of attachment between a child and the mother has proven to be one of the critical factors in child development. It correlates significantly with child's cool EF skills and found non-significant with child's hot EF skill. Meanwhile, the correlation of the child attachment quality with their father in current research resulted in a non-significant relationship, neither in child's cool nor hot EF. Based on this research findings, it was important for the parent to take into consideration their quality of relationship with 
their children in the early childhood because their interaction in attachment relationship with children contributes to the organization of cognitive development that has proven resulted in child ability to regulate their behavior as a focus of early education. The parent could improve their quality of attachment to their children by appropriately and consistently responsive to their children need signal and also showing affectionate behavior toward their children.

\section{REFERENCES}

Anderson, P., \& Reidy, N. (2012). Assessing Executive Function in Preschoolers. Neuropsychology Review, 22, 345360.DOI 10.1007/s11065-012-9220-3

Belsky, J., \& de Haan, M. (2011). Annual Research Review: Parenting and children's brain development: The end of the beginning. Journal of Child Psychiatry, 52 (4), 409-428. DOI 10.1111/j.1469-7610.2010.02281.x

Bernier, A., Beauchamp, M., Carlson, S., \& Lalonde, G. (2015). A secure base from which to regulate: Attachment security in toddlerhood as a predictor of executive functioning at school entry. Developmental Psychology, 51 (9), 1177-1189. DOI $10.1037 / \operatorname{dev} 0000032$

Bernier, A., Carlson, M., \& Whipple, N. (2012). From external regulation to selfregulation: Early parenting precursors of young children's executive functioning. Child Development, 81, 326-339. DOI 10.1111/j.14678624.2009.01397.x

Blair, C. (2016). Executive function and early childhood education. Current Opinion in Behavioral Science, 17, 1-6.

Blair, C., \& Razza, R. (2007). Relating effortful control, executive function, and false belief understanding to emerging math and literacy ability in kindergarten. Child Development, 78 (2), 647-663. DOI 10.1111/j.14678624.2007.01019.x

Bohlin, G., Eninger, L., Broki, K., \& Thorell, L. (2012). Disorganized attachment and inhibitory capacity: Predicting externalizing problem behaviors. Journal of Abnormal Child Psychology, 40, 449-458. DOI 10.1007/s10802011-9574-7

Bretherton, I. (2010). Father in attachment theory and research: A review. Early Child Development and Care, 180, 923.DOI 10.1080/03004430903414661

Bureau, J.-F., Yurkowski, K., Schimedel, S., Martin, J., Moss, E., \& Pallanca, D. (2014). Making Children Laugh: Parent-Child Dyadic Synchrony and Preschool Attachment. Infant Mental Health Journal, 35 (5), 482494.DOl10.1002/imhj.21474

Carlson, S. (2009). Social Origins of Executive Function Development. New Directions for Child and Adolescent Development, 61-74.

Carlson, S., White, R., \& Davis-Unger, A. (2014). Evidence for a relation between executive function for early reading development and education. Early Education and Development, 29, 24-36.

Carlson, S., Zelazo, P., \& Faja, S. (2013). Executive Function. Oxford Handbook of Development Psychology, 706-742. DOI

10.1093/oxfordhb/9780199958450.001 .0001

Cassidy, J., \& Shaver, P. (2016). Handbook of Attachment: Theory, Research, and Clinical Applications. New York: The Guilford Press.

Cartwright, K. (2012). Insights from cognitive neuroscience: The important of executive function for early reading development and education. Early Education and Development, 23, 2436.DOI 10.1080/10409289.2011.615025

Cole, P., Duncan, L., \& Blaye, A. (2014). Cognitive flexibility predicts early reading skills. Frontiers in Psychology, 5, 1-8.DOI 10.3389/fpsyg.2014.00565

Diamond, A. (2013). Executive Functions. Annual Review of Psychology, 64, 135-168. DOI 10.1146/annurev-psych113011-143750. 
Farnfield, S., \& Holmes, P. (2014). The Routledge Handbook of Attachment: Assessment. New York: Routledge.

Garon, N., Bryson, S., \& Smith, I. (2008). Executive function in preschoolers: A review using integrative framework. Psychological Bulletin, 134 (1), 31-60. DOI 10.1037/0033-2909.134.1.31

Hendrawan, D., Fauzani, F., Fatimah, H., Wijaya, F., \& Kurniawati, F. (2015). The construction of executive function instruments for early child ages in Indonesia: A pilot study. International Conference of Child and Adolescence Mental Health. Jakarta.

Hertyas, I., Hendrawan, D., Arbiyah, N., \& Nurbatari, R. (2018). The contribution of parental autonomy support and control on executive function among preschooler. In Amarina A. Ariyanto, H. Muluk, P. Newcombe, F. P. Piercy, E. Kristi Poerwandari, Sri Hartati R. Suradijono, Diversity in unity: Perspective from Psychology and Behavioral Sciences. Taylor \& Francis Group, London, pp. 481-488.

Hughes, C., \& Ensor, R. (2009). How do families help or hinder the emergence of early executive function? In C. Lewis, \& J. Carpendale, Social interaction and the development of executive function, 123, (pp. 35-50). New Directions in Child and Adolescent Development. DOI $10.1002 / \mathrm{cd} .234$

Jacobsen, T., Huss, M., Fendrich, M., Kruesi, M., \& Ziegenhain, U. (1997). Children's ability to delay gratification: Longitudinal relations to mother-child attachment. The Journal of Genetic Psychology, 158 (4), 411-426. DOI: $10.1080 / 00221329709596679$

Lewis, C., \& Carpendale, J. I. M. (2009). Introduction: Links between social interaction and executive function. In C. Lewis \& J. I. M. Carpendale (Eds.), Social interaction and the development of executive function. New Directions in Child and Adolescent Development, 123, $1-15$

Marvin, R. S., Britner, P. A., \& Russel, B. S. (2016). Normative Development: The Ontology of Attachment in Childhood.
In J. Cassidy, \& P. R. Shaver, Handbook of Attachment: Theory, Research, and Clinical Applications ( $\mathrm{p}$. 273). New York: The Guilford Press.

Meuwissen, A., \& Carlson, S. (2015). Fathers matter: The role of father parenting in preschoolers' executive function development. Journal of Experimental Child Psychology, 140, 1-15. DOI 10.1016/j.jecp.2015.06.010

Moss, E., Tarabulsy, M. G., St-Georges, R., Dubois-Comtois, K., Cyr, C., Bernier, A., Lecomte, V. (2014). Videofeedback intervention with maltreating parents and their children: Program implementation and case study. Attachment \& Human Development, 16, 329-342. DOI: $10.1080 / 14616734.2014 .912486$

Posada, G., Kaloustian, G., Richmond, M., \& Moreno, A. (2007). Maternal secure base support and preschoolers' secure base behavior in natural environments. Attachment and Human Behavior, 9 (4), 393-411. DOI: $10.1080 / 14616730701712316$

Raikes, H., \& Thompson, R. (2008). Attachment security and parenting quality predict children's problem solving, attribution, and loneliness with peers. Attachment and Human Development, 10, 319-344.

Rosche, J. (2013). Early attachment and the development of executive function and self-regulatory abilities. Unpublished Dissertation.

Schore, A. (2001). Effect of a secure attachment: Relationship on right brain development, affect regulation, and infant mental health. Infant Mental Health Journal, 22, 7-66. DOI 10.1002/10970355(200101/04)22:1<7::AIDIMHJ2>3.0.CO;2-N

Setyowati, Y., Krisnatuti, D., \& Hastuti, D. (2017). Pengaruh kesiapan menjadi orang tua dan pola asuh psikososial terhadap perkembangan sosial anak. Jurnal IImu Keluarga dan Konsumen, 95-106.

$\mathrm{DOI}$ 10.24156/jikk.2017.10.2.95 
Thorell, L., Rydell, A., \& Bohlin, G. (2012). Parent-child attachment and executive functioning in relation to ADHD symptoms in middle childhood. Attachment \& Human Development, 14, 517-532. DOI: 10.1080/14616734.2012.706396

Towe-Goodman, N., Willoughby, M., Blair, C., Gustafson, H., Mills-Koonce, W., \& Cox, M. (2014). Fathers' sensitive parenting and the development of early executive functioning. Journal of Family Psychology, 28 (6), 867-876. DOI 10.1037/a0038128

Verschueren, K., \& Marcoen, A. (1999). Representation of Self and Socioemotional Competence in Kindergartners: Differential and Combined Effect of Attachment to Mother and to Father. Child Development, 70, 183-201.DOI 10.1111/1467-8624.00014

Villano, N., Sapuppo, W., Sannino, A., Parrella, R., Bisogno, R., \& Caviglia, G. (2014). Working memory abilities, attachment relationship and learning process in children of primary school age: An empirical research. Research in Psychotherapy: Psychopathology, Process, and Outcome, 21-32. DOI 10.4081/ripppo.2014.134

Waters, F. S., \& Thompson, A. R. (2016). Children's perceptions of emotion regulation strategy effectiveness: Link with attachment security. Attachment \& Human Development, 1-19. DOI 10.1080/14616734.2016.1170051
Welsh, J. S., Nix, R. L., Blair, C., Bierman, K. L., \& Nelson, K. E. (2010). The Developmment of Cognitive Skills and Gains in Academic School Readiness for Children From Low Income Families. Journal of Educational Psychology, 102 (1), 4553

Whipple, N., Bernier, A., \& Mageau, G. (2011). A dimensional approach to maternal attachment state of mind: A relations to maternal sensitivity and maternal autonomy support. Developmental Psychology, 47 (2), 396-403. DOI $10.1037 / \mathrm{a} 0021310$.

Williford, A., Carter, L., \& Pianta, R. (2016). Attachment and School Readiness. In J. Cassidy, \& P. Shaver, Handbook of Attachment: Theory, Research and Clinical Applications (pp. 966-982). New York: The Guilford Press.

Zelazo, P. (2006). The dimensional change card sort (DCSS): A method of assessing executive function in children. Natura Protocols-Electronic Edition. DOI 10.1038/nprot.2006.46

Zelazo, P., \& Carlson, S. (2012). Hot and Cool Executive Function in Childhood and Adolescence: Development and Plasticity. Child Development Perspective, 6, 354-360. DOI 10.1111/j.1750-8606.2012.00246.x

Zelazo, P., \& Muller, U. (2011). Executive function in typical and atypical development. In U. Goswami, Blackwell Handbook of Childhood Cognitive Development. USA: Blackwell Publishers Ltd. 